\title{
Hemoprotective and nephroprotective potentials of aqueous extract of Jussiaea nervosa leaf in cadmium exposed albino rats.
}

\author{
Ibiam, U. A. ${ }^{1}$, Ugwuja, E. I . ${ }^{2}$, Ejeogo, C. ${ }^{3}$, Aja, P. M. ${ }^{1}$, Afiukwa ${ }^{4}$, C., Oji, O ${ }^{1}$. \\ U. and Uraku, A. J. ${ }^{1}$ \\ ${ }^{1}$ Department of Biochemistry, ${ }^{4}$ Department of Biotechnology, Faculty of Biological Sciences, Ebonyi State \\ University, Abakaliki \\ ${ }^{2}$ Department of Chemical Pathology, Faculty of Clinical Medicine, Ebonyi State University, PMB 053 \\ Abakaliki, Nigeria \\ ${ }^{3}$ Department of Biochemistry, Institute of Management and Technology (IMT), Enugu
}

\begin{abstract}
In this study, the hemoprotective and nephroprotective potentials of aqueous extract of Jussiaea nervosa leaves on cadmium-exposed rats were evaluated. In the first experiment, 24 Wister albino rats divided into 6 groups: A-F of 4 rats per group were used for the evaluation of $C d$ toxicity. While group A rats received water and feed only and served as negative control (NC), groups B-F received in addition to water and feed, 1 , $2,4,8 \& 12 \mathrm{mg} / \mathrm{kg}$ body weight of Cd, respectively for 6 weeks. Based on the significant effect of Cd at $12 \mathrm{mg} / \mathrm{kg}$ body weight in the first experiment, additional group $(G)$, exposed to $12 \mathrm{mg} / \mathrm{kg}$ body weight of $\mathrm{Cd}$ was established for the assessment of the hemoprotective and nephroprotective potentials of J. nervosa in Cdexposed rats. This group $(n=12)$ was subdivided into four subgroups $(G 1, G 2, G 3$ and G4) of 3 rats each. Subgroup G1 was maintained on normal feed and water and served as the positive control (PC) while G2, G3 and G4 were given 20, 50 and $100 \mathrm{mg} / \mathrm{kg}$ doses of aqueous Jussiaea nervosa extract, respectively. All feedings and treatment also lasted for six weeks. At the end of the experiment, the animals were sacrificed and blood and kidney samples were collected for laboratory analyses. Biochemical and histological analyses were done using standard laboratory techniques. Exposure to cadmium was observed to cause significant $(p<0.05)$ decreases in packed cell volume $(P C V)$, hemoglobin concentration $(H B C)$, and total white blood cell count $(T W B C)$ and increases in plasma urea, creatinine \& electrolytes. However, administration of aqueous extract of J. nervosa ameliorated these $C d$-induced effects in a dose-related manner, with higher doses $(50 \mathrm{mg} / \mathrm{l} \& 100 \mathrm{mg} / \mathrm{l})$ almost restoring the parameters to the levels in non-exposed rats. Additionally, the Cd-induced changes in the histology of the kidneys were almost restored by administration of Jussiaea nervosa extract. We conclude that J. nervosa may possess haemoprotective and nephroprotective potentials and its regular consumption may protect against cadmium toxicity.
\end{abstract}

Key words: Jussiaea nervosa, Cd-intoxication, hematoprotection, nephroprotection

\section{Introduction}

Cadmium (Cd) has been classified as a category one carcinogen by International Agency for Research on Cancer. It causes cancer of the lungs, pancrease, prostate and kidney[1] .The general population is facing an increasing risk of $\mathrm{Cd}$ exposure and the attendant health hazards associated with it are of immense concern. One of the main sources of $\mathrm{Cd}$ exposure is cigarette smoke[2]. In addition, $\mathrm{Cd}$ is found in ambient air in occupationally exposed situations and in paints [3].

In recent times, the use of traditional medicine is increasingly gaining popularity in both the developed and developing Worlds. It has been estimated that about $80 \%$ of the people in developing countries rely on traditional medicine for their health care [4]. In Nigeria, the effectiveness of some indigenous plants in the treatment of various ailments is no longer in doubt [5].

Jussiaea nervosa is one of the herbal plants popularly used for treating various diseases. Its uses include poison antidote, treatment of alcohol intoxication, diarrhoea, dysentery, vomiting, just to mention a few [6]. The parts of the plant usually used for treatment of diseases are the leaves and soft stems. Jussiaea nervosa is of the family of Onagracea. The common local names include arira mmili (Igbo), sha shatau (Hausa), and ewuru odo (Yoruba).

Considering the ease with which humans are exposed to $\mathrm{Cd}$, both at home (terrestrial foods, drinking water, cigarette), work places and the abundance of Jussiaea nervosa in our environment, it has become pertinent to scientifically evaluate whether the consumption of the leaf extract will protect against $\mathrm{Cd}$ toxicity.

The aim of the present study is to determine the hemoprotective and nephroprotective potentials of aqueous leaf extract of Jussiaea nervosa in Cd-exposed rats. 


\section{Materials and Methods}

\subsection{Preparation of extract}

The leaves of Jussiaea nervosa was collected from a farm in a swampy area of phase 6, Trans-Ekulu, Enugu East Local Government Area of Enugu State, Nigeria. The plant was identified and authenticated by Prof. J.C. Okafor, a Consultant Agro forester and Taxonomist, University of Nigeria, Nsukka. The leaves were washed and sun-dried to constant weight and ground into powder with a manual grinder. The resulting powder was soaked in distilled water and boiled on slow heat for about two hours.

The preparation was then suction-filtered and the process repeated until all the soluble compounds had been extracted. This was judged by loss of color of the filtrate. The extract was concentrated to dryness at $60{ }^{\circ} \mathrm{C}$ using electric oven. It was carefully evaporated to dryness on water bath at $40{ }^{\circ} \mathrm{C}$ [7] and the extract stored in a refrigerator until use.

\subsection{Animals and treatment}

Male Wister albino rats $(\mathrm{n}=24)$ weighing 105-162 g purchased from animal house of the Department of Pharmacy, University of Nigeria, Nsukka were randomly assigned into six (6) groups (A-F) of five (4) rats per group. The animals were allowed free access to feed and water ad libitu for a period of one week to allow them acclimatize. All the rats received human care in accordance with the National Institute of Health guidelines for the care and use of laboratory animals [8].

Group A rats served as negative control (NC) and were given only water and feeds. Groups B, C, D, E and $\mathrm{F}$ were exposed to $\mathrm{Cd}$ at concentrations of $1,2,4,8$ and $12 \mathrm{mg} / \mathrm{kg}$ of body weight respectively, for six weeks. They were also fed with water and feeds ad libitum. The effect of Cadmium observed in rats exposed to $12 \mathrm{mg} / \mathrm{kg}$ body weight was found to be most significant and this informed the use of $12 \mathrm{mg} / \mathrm{kg} \mathrm{Cd}$-concentration in subsequent study involving herbal intervention with Jussiaea nervosa extracts. In this segment of the study, additional group $(\mathrm{G})$ was established. This group containing 12 rats was sub-divided into $4: \mathrm{G}_{1}, \mathrm{G}_{2}, \mathrm{G}_{3}$ and $\mathrm{G}_{4}$ sub-groups, with each sub-group containing 3 rats. While sub-group $\mathrm{G}_{1}$ rats were given water and feed only and served as positive controls (PC), sub-groups $\mathrm{G}_{2}, \mathrm{G}_{3}$, and $\mathrm{G}_{4}$ rats were given 20,50 and $100 \mathrm{mg} / \mathrm{kg}$ body weight of Jussiaea nervosa extract in addition to water and feed, respectively.

All feeding and treatments were for six weeks duration. At the end of the experiment, the rats were anaesthetized in a chloroform saturated chamber and sacrificed. Blood samples were taken from each of the rats for haematological and biochemical analysis, while the kidneys were excised for histopathological analysis.

\subsection{Sample analyses}

Hematological parameters \{packed cell volume (PCV), hemoglobin concentration (HBC), total white blood cell count (TWBC) \} were analyzed as described by Dacie and Lewis [9], plasma urea was determined by the method described by Jung et al.[10] and creatinine estimation was done by method originally described by Benedict and Behie [11] and reevaluated by Stevens et al. [12], plasma potassium $\left(\mathrm{K}^{+}\right)$and sodium $\left(\mathrm{Na}^{+}\right)$were determined by flame atomic absorption spectrophotometer, bicarbonate $\left(\mathrm{HCO}^{-}\right)$was determined by titration in accordance with the method described by Van Slyke [13], Serum chloride $\left(\mathrm{Cl}^{-}\right)$was estimated by the mercuric nitrate colorimetric method described by Skeggs and Hochstrasser [14].

The histopathological analysis of the kidney was carried out using standard methods according to Talib and Khurana [15].

\subsection{Statistical analysis}

Results were expressed as mean \pm standard deviation. Comparison of parameters among groups was done by one-way analysis of variance (ANOVA) with statistical significance achieved at $\mathrm{p}<0.05$.

\section{Results}

Table1: Effects of Cadmium exposure on hematological parameters of Cadmium exposed albino rat

\begin{tabular}{ccccc}
\hline $\begin{array}{c}\text { Rat } \\
\text { groups }\end{array}$ & $\begin{array}{c}\text { Cadmium dose } \\
(\mathrm{mg} / \text { Kg body weight })\end{array}$ & $P C V(\%)$ & $H B C(g / d l)$ & $T W B C\left(x 10^{9} / l\right)$ \\
\hline A & 0.0 & $52.66 \pm 1.35^{\mathrm{a}}$ & $17.37 \pm 0.36^{\mathrm{a}}$ & $6.40 \pm 0.87^{\mathrm{a}}$ \\
$\mathrm{B}$ & 1.0 & $48.33 \pm 0.96^{\mathrm{a}}$ & $14.60 \pm 0.29^{\mathrm{a}}$ & $5.60 \pm 0.66^{\mathrm{a}}$ \\
C & 2.0 & $38.66 \pm 1.35^{\mathrm{b}}$ & $12.90 \pm 0.58^{\mathrm{b}}$ & $5.00 \pm 0.64^{\mathrm{a}}$ \\
$\mathrm{D}$ & 4.0 & $35.60 \pm 2.50^{\mathrm{b}}$ & $11.73 \pm 0.68^{\mathrm{b}}$ & $4.7 \pm 0.58^{\mathrm{b}}$ \\
E & 8.0 & $32.00 \pm 2.87^{\mathrm{b}}$ & $9.90 \pm 0.12^{\mathrm{b}}$ & $4.00 \pm 0.18^{\mathrm{b}}$ \\
F & 12.0 & $28.60 \pm 1.35^{\mathrm{bc}}$ & $6.36 \pm 1.35^{\mathrm{bc}}$ & $3.10 \pm 1.12^{\mathrm{bc}}$ \\
\hline
\end{tabular}


PCV: Packed cell volume; HBC: Hemoglobin concentration; TWBC: Total white blood cell count. Values are expressed as mean $\pm \mathrm{s}$. d. Values with different superscripts are significantly different.

From table 1, exposure to cadmium was observed to have adverse effect on the hematological parameters of the exposed rats with packed cell volume, hemoglobin concentration and total white blood cell count significantly decreasing with increasing doses of cadmium. However, at cadmium dose of $12 \mathrm{mg} / \mathrm{Kg}$ body weight of the rats, PCV, HBC and TWBC were found to decrease by $45.7 \%, 63.4 \%$ and $51.6 \%$, respectively.

Table 2: Effects of aqueous extract of Jussiaea nervosa leaf on hematological parameters of cadmium exposed albino rats

\begin{tabular}{lllll}
\hline Rat groups & Extract dose $(g / l)$ & $P C V(\%)$ & $H B C(g / d l)$ & $T W B C\left(x 10^{9} / l\right)$ \\
\hline $\mathrm{A}$ & $0.0(\mathrm{NC})$ & $52.66 \pm 1.35^{\mathrm{a}}$ & $17.37 \pm 0.36^{\mathrm{a}}$ & $6.40 \pm 0.87$ \\
$\mathrm{G}_{1}$ & $0.0(\mathrm{PC})$ & $28.60 \pm 1.35^{\mathrm{b}}$ & $6.36 \pm 1.35^{\mathrm{b}}$ & $3.90 \pm 0.12^{\mathrm{b}}$ \\
$\mathrm{G}_{2}$ & 20.0 & $49.00 \pm 0.57^{\mathrm{a}}$ & $15.58 \pm 1.20^{\mathrm{a}}$ & $7.23 \pm 0.73^{\mathrm{a}}$ \\
$\mathrm{G}_{3}$ & 50.0 & $52.66 \pm 1.35^{\mathrm{a}}$ & $17.66 \pm 0.12^{\mathrm{a}}$ & $8.80 \pm 0.11^{\mathrm{a}}$ \\
$\mathrm{G}_{4}$ & 100.0 & $55.33 \pm 3.43^{\mathrm{a}}$ & $19.33 \pm 0.10^{\mathrm{a}}$ & $9.10 \pm 0.64^{\mathrm{a}}$ \\
\hline
\end{tabular}

NC: Negative control; PC: Positive control; PCV: Packed cell volume; HBC: Hemoglobin concentration; TWBC: Total white blood cell count. Values are expressed as mean $\pm \mathrm{s}$. d. Values with different superscripts are significantly different.

Table 2 shows the effects of $J$. nervosa on the hematological parameters of cadmium exposed rats. Although hematological parameters in cadmium exposure rats were found to be significantly $(\mathrm{p}<0.05)$ lower in comparison to the non-exposed rats, administration of aqueous extract of $J$. nervosa showed ameliorative effects. These ameliorative effects were observed to be dose dependent, with higher doses $(50 \mathrm{mg} / 1$ \& $100 \mathrm{mg} / \mathrm{l})$ in addition to restoring the parameters to the levels in non exposed rats, tends to cause increases in these parameters above the values found in non- exposed group.

Table 3: Effects of cadmium exposure on plasma urea, creatinine and electrolytes in cadmium exposed albino rats

\begin{tabular}{lcllllll}
\hline \multirow{2}{*}{$\begin{array}{l}\text { Rat } \\
\text { groups }\end{array}$} & $\begin{array}{l}\text { Cd } \\
\text { dose }\end{array}$ & Urea & Creatinine & \multicolumn{2}{c}{ Electrolytes } \\
\cline { 4 - 7 } & & & $\mathrm{K}^{+}$ & $\mathrm{Na}^{+}$ & $\mathrm{Cl}^{-}$ & $\mathrm{HCo}_{3}^{-}$ \\
\hline $\mathrm{A}$ & 0 & $5.38 \pm 0.42^{\mathrm{a}}$ & $65.75 \pm 0.14^{\mathrm{a}}$ & $3.58 \pm 0.01^{\mathrm{a}}$ & $134.18 \pm 0.22^{\mathrm{a}}$ & $101.50 \pm 0.52^{\mathrm{a}}$ & $25.43 \pm 1.49^{\mathrm{a}}$ \\
$\mathrm{B}$ & 1 & $7.07 \pm 0.10^{\mathrm{a}}$ & $89.45 \pm 1.18^{\mathrm{b}}$ & $5.25 \pm 0.17^{\mathrm{a}}$ & $135.53 \pm 0.21^{\mathrm{a}}$ & $103.30 \pm 2.14^{\mathrm{a}}$ & $26.45 \pm 0.32^{\mathrm{a}}$ \\
$\mathrm{C}$ & 2 & $8.12 \pm 0.30^{\mathrm{a}}$ & $94.25 \pm 3.06^{\mathrm{b}}$ & $5.07 \pm 0.37^{\mathrm{a}}$ & $137.06 \pm 0.09^{\mathrm{a}}$ & $105.93 \pm 0.04^{\mathrm{a}}$ & $25.63 \pm 0.39^{\mathrm{a}}$ \\
$\mathrm{D}$ & 4 & $10.36 \pm 0.28^{\mathrm{b}}$ & $95.27 \pm 2.84^{\mathrm{b}}$ & $5.34 \pm 0.25^{\mathrm{a}}$ & $139.18 \pm 0.09^{\mathrm{a}}$ & $107.78 \pm 0.64^{\mathrm{a}}$ & $28.59 \pm 0.35^{\mathrm{a}}$ \\
$\mathrm{E}$ & 8 & $12.28 \pm 0.43^{\mathrm{b}}$ & $108.08 \pm 1.74^{\mathrm{c}}$ & $5.80 \pm 0.57^{\mathrm{a}}$ & $141.07 \pm 0.09^{\mathrm{b}}$ & $109.66 \pm 0.27^{\mathrm{a}}$ & $29.23 \pm 0.52^{\mathrm{a}}$ \\
$\mathrm{F}$ & 12 & $16.38 \pm 0.09^{\mathrm{bc}}$ & $114.12 \pm 0.69^{\mathrm{c}}$ & $6.10 \pm 0.75^{\mathrm{b}}$ & $145.20 \pm 0.06^{\mathrm{b}}$ & $110.44 \pm 0.18^{\mathrm{b}}$ & $31.49 \pm 0.96^{\mathrm{b}}$ \\
\hline
\end{tabular}

The effects of exposure to cadmium on plasma urea, creatinine and electrolytes were shown in table 3. Exposure to cadmium was observed to cause impairment in renal functions in dose dependent manner, with higher doses having more severe effects as demonstrated by higher elevations in plasma urea and creatinine at higher doses. Additionally, cadmium toxicity was observed to affect plasma urea and creatinine (which almost tripled and doubled respectively at $\mathrm{Cd}$ dose of $12 \mathrm{mg} / \mathrm{Kg}$ body weight) more than the electrolytes, except for potassium which almost doubled at the same cadmium dosage.

Table 4: Effects of aqueous extract of Jussiaea nervosa on plasma urea, creatinine and electrolytes in cadmium exposed albino rats

\begin{tabular}{|c|c|c|c|c|c|c|c|}
\hline \multirow{2}{*}{$\begin{array}{l}\text { Rat } \\
\text { groups }\end{array}$} & \multirow{2}{*}{$\begin{array}{l}\mathrm{Cd} \\
\mathrm{dos} \\
\mathrm{e}\end{array}$} & \multirow[t]{2}{*}{ Urea } & \multirow[t]{2}{*}{ Creatinine } & \multicolumn{3}{|c|}{ Electrolytes } & \multirow[b]{2}{*}{$\mathrm{HCo}_{3}{ }^{-}$} \\
\hline & & & & $\mathrm{K}^{+}$ & $\mathrm{Na}^{+}$ & $\mathrm{Cl}^{-}$ & \\
\hline$\overline{\mathrm{A}}$ & $\mathrm{NC}$ & $\begin{array}{l}5.38 \pm 0.42 \\
\text { a }\end{array}$ & $\begin{array}{l}65.75 \pm 0.14 \\
\text { a }\end{array}$ & $\begin{array}{l}3.58 \pm 0.0 \\
1^{\mathrm{a}}\end{array}$ & $\begin{array}{l}134.18 \pm 0.2 \\
2^{\mathrm{a}}\end{array}$ & $\begin{array}{l}101.50 \pm 0.5 \\
2^{\mathrm{a}}\end{array}$ & $25.43 \pm 1.49$ \\
\hline $\mathrm{G}_{1}$ & $\mathrm{PC}$ & $\begin{array}{l}16.60 \pm 0.0 \\
9^{\mathrm{b}}\end{array}$ & $\begin{array}{l}114.12 \pm 0.6 \\
2^{b}\end{array}$ & $\begin{array}{l}6.10 \pm 0.7 \\
5^{b}\end{array}$ & $\begin{array}{l}145.20 \pm 0.1 \\
6^{b}\end{array}$ & $\begin{array}{l}110.44 \pm 0.1 \\
8^{b}\end{array}$ & $\begin{array}{l}31.49 \pm 0.94 \\
\mathrm{~b}\end{array}$ \\
\hline $\mathrm{G}_{2}$ & 20 & $\begin{array}{l}16.00 \pm 0.2 \\
9^{\mathrm{b}}\end{array}$ & $\begin{array}{l}112.17 \pm 3.0 \\
7^{\mathrm{b}}\end{array}$ & $\begin{array}{l}5.51 \pm 0.0 \\
5^{\mathrm{b}}\end{array}$ & $\begin{array}{l}143.90 \pm 0.1 \\
2^{\mathrm{b}}\end{array}$ & $\begin{array}{l}108.47 \pm 0.0 \\
4^{b}\end{array}$ & $\underset{\mathrm{a}}{29.14 \pm 0.94}$ \\
\hline
\end{tabular}


Haemoprotective and nephroprotective potentials of aqueous extract of Jussiaea nervosa leaf in

\begin{tabular}{llllllll}
\hline $\mathrm{G}_{3}$ & 50 & $15.50 \pm 0.2$ & $110.13 \pm 3.9$ & $5.05 \pm 0.2$ & $140.90 \pm 0.1$ & $105.40 \pm 0.4^{\mathrm{a}}$ & $28.53 \pm 0.49$ \\
& & $5^{\mathrm{b}}$ & $7^{\mathrm{b}}$ & $1^{\mathrm{b}}$ & $8^{\mathrm{b}}$ & & \\
$\mathrm{G}_{4}$ & 100 & $15.00 \pm 0.0$ & $108.80 \pm 2.2$ & $4.00 \pm 0.2$ & $130.05 \pm 0.2$ & $103.05 \pm 0.2$ & $26.08 \pm 0.59$ \\
& & $7^{\mathrm{b}}$ & $5^{\mathrm{b}}$ & $0^{\mathrm{a}}$ & $0^{\mathrm{a}}$ & $0^{\mathrm{a}}$ & ${ }^{\mathrm{a}}$ \\
\hline
\end{tabular}

Values are expressed as mean \pm s. d. Values with different superscripts are significantly different.

Although administration of aqueous extract of $J$. nervosa at higher doses improved the electrolyte status in cadmium-induced renal impairment, with plasma $\mathrm{K}^{+}, \mathrm{Na}^{+}, \mathrm{Cl}^{-}$, and $\mathrm{HCO}_{3}^{-}$, which were elevated in untreated rats almost returned to levels found in non-exposed rats, at $J$. nervosa dosage of $12 \mathrm{mg} / \mathrm{Kg}$ body weight, the effects on plasma urea and creatinine were non-significant (Table 4).

Histological analysis showed high degree of damage to the kidney characterised by severe congestion and infiltration of inflammatory cells, widespread injury on glomeruli, haemorrhage, pkynosis and excessive necrosis in Cd-exposed rats (Figure 2) in comparison to the control (Figure 1). However, administration of Jussiaea nervosa extract exerted nephroprotective effects with mild to moderate congestion and peripheral preservation of kidney architecture (Figure 3).

\section{Discussion}

This study has documented decreased hematological parameters and impaired renal function with plasma urea and creatinine elevated in Cd-exposed rats. These effects, which are dose dependent, were found to be ameliorated/restored by aqueous extract of J. nervosa. Significant decreases in hematological parameters (hemoglobin concentration and packed cell volume) observed in the present study is in corroboration with the findings of El-Demerdash et al. [16]. In a similar study, Horiguchi et al [17] reported decreased peripheral white blood cells in $\mathrm{Cd}$ administered rats. The toxicity and toxic effects of cadmium generally result from the binding of the metal with reactive and/or complex groups leading to inhibition of enzymatic process, possibly disturbing general growth, development and reproduction [3].

The significant decrease in the haemoglobin concentrations may be due to either an increase in the rate at which the hemoglobin is destroyed or to a decrease in the rate of haemoglobin synthesis. In addition to the established hemorrhage associated with $\mathrm{Cd}$ toxicity [18] decreased haematological parameters observed in the present study may be partly attributed to impaired renal functions. Impaired renal function in Cd-exposed rats, as evidenced by elevated plasma urea and creatnine as well as electrolyte imbalance suggests the likelihood of kidney damage as the cause of decreased haematological parameters.

It has been reported that kidney damage is associated with reduced erythropoietin production and excess breakdown of blood protein [19] with a resultant decrease in hematological parameters. However, it has been proposed that the mechanisms by which $\mathrm{Cd}$ induce anaemia include decreased iron absorption, distortion of erythropoiesis and hemolysis of red blood cells [20,21]. Kidney damage has long been described to be the main problem for patients chronically exposed to cadmium [22]. This is in corroboration with the findings of the present study where Cd-exposed rats were observed to have elevated plasma urea and creatinine as well as electrolyte imbalance.

Cadmium induces kidney damage through the formation of cadmium-metallothionein (Cd-MT) complex. Cd-MT complex is filtrated in the glomerulus, and subsequently reabsorbed in the proximal tubulus where it remains and makes up the major part of the cadmium body burden. It has been proposed that the amount of cadmium in the kidney tubular cells increases during every person's life span. The severe congestion, infiltration of inflammatory cells, widespread injury on glomeruli, hemorrhage, pkynosis and excessive necrosis observed in the liver of $\mathrm{Cd}$ exposed rats (Figure 2) in comparison to the unexposed rats (Figure 1) and the preservation of kidney architecture with moderate congestion (Figure 3) observed after treatment with Jussiaea nervosa leave extract observed in the present study, suggests nephroprotective potentials of the extract. This reaffirms earlier suggestion of impaired kidney function as the cause of electrolyte imbalance and increased plasma urea and kidney. Although we did not encounter any study on the effect of J. nervosa in Cd-exposed rats, protective effects of some herbs have been reported. For instance, the hepatoprotective effect of onion and garlic extracts on cadmium $(\mathrm{Cd})$-induced oxidative damage in rats have been reported [23, 24].

Though the mechanism of the observed effects are not yet clear at this stage of the work, however, Jussiaea nervosa, like most of other plants contains phytochelatins which bind to metallic ions through metal chelation mechanism to form mercaptide complexes [25]. Cadmium is apparently bound reversibly to metallothionein (Cd-MT). Metallothionein has also been reported to play an important protective role in the heavy metal toxicity via the formation of metal-metallothionein complexes [26]. Thus it is possible that phytochelatin form complexes with $\mathrm{Cd}^{2+}$ and neutralize its toxicity [27]. 


\section{Conclusion}

The restoration of hematological parameters and renal function by aqueous extract of J. nervosa suggest its hematorpotective and nephroprotective potentials. We therefore conclude that regular consumption of Jussiaea nervosa leaf may be protective against Cd toxicity.

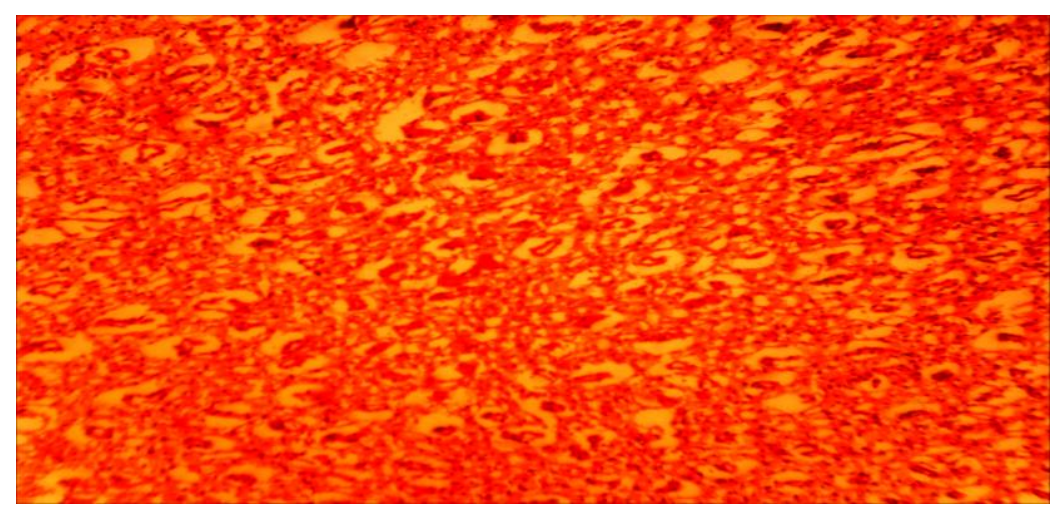

Figure1: Micrograph of the section of the kidney of albino rat which was fed with only water and rat feeds (NC). The section shows normal kidney architecture with well preserved glomeruli.

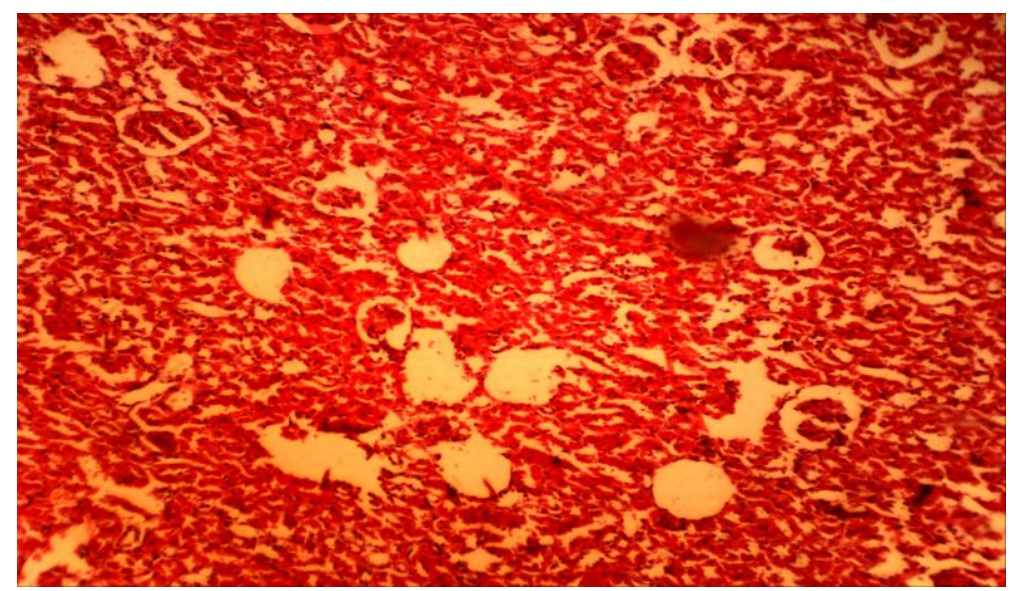

Figure 2: Micrograph of a section of the kidney of albino rat exposed to $12 \mathrm{mg} / \mathrm{kg}$ of Cd. The plate shows widespread injury on glomeruli and pkynosis, hemorrhage, severe congestion and extensive necrosis.

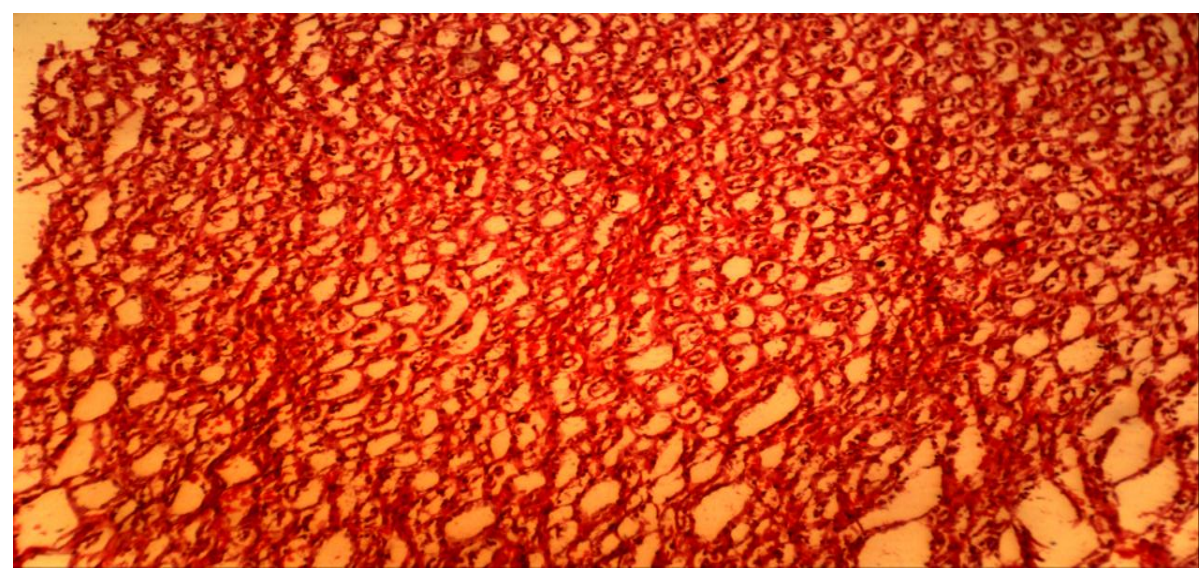

Figure 3: Micrograph of the section of the kidney of albino rat exposed to $12 \mathrm{mg} / \mathrm{Kg}$ of Cd concentration and treated with Jussiaea nervosa water extract. The section shows preserved glomeruli. 


\section{References}

[1] International Agency for Research on Cancer (IARC). 1993. Berylium, cadmium, mercury and exposures in Glass Manufacturing Industry in Monographs on the evaluation of carcinogenic risk. Human Scientific Publications (58): 119-237

[2] Bem, E.M., Piotrowski., J.K., and Turzynska., T. 1993. Cadmium, zinc and copper levels in the kidneys and liver of the inhabitants of North-Eastern Poland Journal of Occupational Medicare and Environmental Health (6):133-141.

[3] World Health Organization. 1992. Environmental health criteria, 134, cadmium. Geneva: World Health Organization; Pp 111-2.

[4] Latif, A., Ahmad, H., Begum, S., Hussian, S.K., and Adnan, M. 2004. Medicinal and other economic plants as substitute to forest logging in miandam and sulatann valley-Swat. Bioactive molecules and medicinal plants 54(4): 349-369.

[5] Sofowora, A. 1986. The State of Medicinal Plants in Nigeria. University of Ibadan Press, Ibadan. Pp 419.

[6] Sadiq, D., Ezi-Ashi, T., and Onuaguluchi, G. 2003. Checklist of medicinal plants of Nigeria and their uses. $1^{\text {st }}$ edition. A publication of the Association Conservation and Utilization of Medicinal Plants in Nigeria, Asicumptipn Enugu, Nigeria Pp 64-73.

[7] Sofowora A. (1997). The State of Medicinal Plants $1^{\text {st }}$ edition. University of Ibadan, Press Nigeria, Pp 286.

[8] National Research Council (NRC). 1985. Guide for the care and use of laboratory animals. Publication No. 8523 (Rev), National Institute of Health, Bethesda, MD.

[9] Dacie JV and Lewis SM. 1995. Practical haematology 8th edition Edinburgh: Churchill Livingstone

[10] Jung D, Briggs N, Erickson J, Ledyard P. 1975. New colorimetric reaction for nd-point continuous flow, and kinetic measurement of urea. Clin Chem 21: 11-36.

[11] Benedict SR, Behre JA. 1936. Some applications of a new colour reaction for creatinine. J Biol Chem 114: 515-532.

[12] Stevens JF, Tsang W, Neewall, RG. 1983. Measurement of bilirubin, cholesterol and creatinine in serum and plasma by solid phase reflectance spectroscopy. J Clin Path 36: 598-601.

[13] Van Slyke D. 1920. Titration method of plasma bicarbonate estimation. J. Biol. Chem 52:495.

[14] Skeggs LTand Hochstrasser HC. 1964. Thiocyanate (colorimetric) method of chloride estimation. Clin Chem 10: 918-920.

[15] Talib, V. H. and Khurana, S. R. 1999. Handbook of Medical laboratory Technology, $2^{\text {nd }}$ edition. C. B. S. Publishers and Distributors, New Delhi, India, Pp 208-305.

[16] El-Demerdash FM, Yousef MI, Kedwany FS, Baghdadi HH. 2004. Cadmium- induced changes in lipid peroxidation, blood hematology, biochemical parameters and semen quality of male rats: protective role of vitamin E and beta-carotene. Food Chem Toxicol 42(10):1563-71.

[17] Horiguchi, H., Oguma, E. and Kayama, F. 2011. Cadmium Induces Anemia through Interdependent Progress of Hemolysis, Body Iron Accumulation, and Insufficient Erythropoietin Production in Rats. Toxicol. Sci. 122 (1): 198-21.

[18] Obianime, AW and Roberts, II. Antioxidants, cadmium-induced toxicity, serum biochemical and the histological abnormalities of the kidney and testes of the male wistar rats. Nigerian Journal of Physiological Sciences 2009; 24 (2): 177 -185

[19] Ezzati, M., and Kainmen., D.M. 2001. Quantifying the Effects of Exposure to indoor air pollution from biomass combustion on acute respiratory infections in developing countries. Environmental Health Perspective 109: 481-8.

[20] Horiguchi H, Teranishi H, Niiya K, Aoshima K, Katoh T, Sakuragawa N, Kasuya M. 1994. Hypoproduction of erythropoietin contributes to anaemia in chronic cadmium intoxication: clinical studies on itai-itai disease in Japan. Arch Toxicol 68: 632-6.

[21] Horiguchi H, Sato M, Konno N, Fukushima M. 1996. Long term cadmium exposure induces anaemia in rats through hypoinduction of erythropoietin in the kidney. Arch Toxicol 71:11-9.

[22] Barbier O, Jacquillet G, Tauc M, Cougnon M, Poujeol P. 2005. Effect of heavy metals on, and handling by, the kidney. Nephron Physiol 99(4): 105-10.

[23] Obioha UE, Suru SM, Ola-Mudathir KF, Faremi TY. 2009. Hepatoprotective potentials of onion and garlic extracts on cadmiuminduced oxidative damage in rats. Biol Trace Elem Res. 129(1-3):143-56.

[24] Suru Sm. 2008. Onion and garlic extracts lessen cadmium-induced nephrotoxicity in rats. Biometals. 21(6):623-33.

[25] Suk-Bong, H,m Aaron, P., Smith, R.H., Wendy, M., Dietrich, S.B., Mathew, J., O'Connell, P.B., and Christopher, S.C. 1999. Phytochelatin Synthase Genes from Arabidopsis and Yeast Schizosaccharomyces pombe. Plant Cell 11(6): 1153-1164.

[26] Elinder, C.G., Nortberg, M., Palm, B., Bjork, L and Jonsson, L. 1987. Cadmium, zinc and copper in rabbit kidney metallothioneinrelation to kidney toxicity. Environmental Research 42: 553-562.

[27] Ming, Ho Yu. 2000. Environmental Toxicology, $1^{\text {st }}$ edition, Lewis Publishers Washington D.C. USA Pp 151-185. 